Article

\title{
Lead Ion Sorption by Perlite and Reuse of the Exhausted Material in the Construction Field
}

\author{
Andrea Petrella ${ }^{1, *}$, Danilo Spasiano ${ }^{1}\left(\mathbb{D}\right.$, Vito Rizzi $^{2}$, Pinalysa Cosma ${ }^{2}\left(\mathbb{D}\right.$, Marco Race $^{3}{ }^{(1)}$ and \\ Nicoletta De Vietro ${ }^{4}$ \\ 1 Dipartimento di Ingegneria Civile, Ambientale, Edile, del Territorio e di Chimica, Politecnico di Bari, via E. \\ Orabona, 4, 70125 Bari, Italy; danilo.spasiano@poliba.it \\ 2 Dipartimento di Chimica, Università degli Studi di Bari “Aldo Moro”, via E. Orabona, 4, 70125 Bari, Italy; \\ vito.rizzi@uniba.it (V.R.), pinalysa.cosma@uniba.it (P.C.) \\ 3 Dipartimento di Ingegneria Civile e Meccanica, Università di Cassino e del Lazio Meridionale, via Di Biasio \\ 43, 03043 Cassino, Italy; marco.race@unina.it \\ 4 Istituto di Nanotecnologia (Nanotec), Consiglio Nazionale delle Ricerche (CNR), c/o Dipartimento di \\ Chimica, Università degli Studi di Bari “Aldo Moro”, via E. Orabona, 4, 70125 Bari, Italy; \\ nicoletta.devietro@uniba.it \\ * Correspondence: andrea.petrella@poliba.it; Tel.: +39-(0)805-963-275, Fax: +39-(0)805-963-635
}

Received: 26 September 2018; Accepted: 5 October 2018; Published: 11 October 2018

\begin{abstract}
This paper deals with the possibility of using perlite as a lead ion sorbent from industrial wastewater. Dynamic (laboratory column) operations were carried-out using beads, which were percolated by metals in a $2-10 \mathrm{mg} \cdot \mathrm{L}^{-1}$ concentration range. To this purpose, lead ion solutions were eluted in columns loaded with different amounts of sorbent $(2-4 \mathrm{~g})$ within a 1-2 mm bead size range, at $0.15-0.4 \mathrm{~L} \cdot \mathrm{h}^{-1}$ flow-rates. Tests were performed to complete sorbent exhaustion (column breakthrough). The highest retention was obtained at $0.3 \mathrm{~L} \cdot \mathrm{h}^{-1}$, with $4 \mathrm{~g}$ of perlite and $10 \mathrm{mg} \cdot \mathrm{L}^{-1}$ of influent, lead ion concentration. Film diffusion control was the kinetic step of the process in the Nerst stationary film at the solid/liquid interface. At the end of the sorption, perlite beads were used as lightweight aggregates in the construction field (i.e., for the preparation of cement mortars). Specifically, conglomerates showing different weights and consequently different thermal insulating and mechanical properties were obtained, with potential applications in plaster or panels.
\end{abstract}

Keywords: perlite; column experiment; sorption; film diffusion control; wastewater treatment; cement mortar; thermal measurements; mechanical resistances

\section{Introduction}

Anthropogenic activity causes the direct and indirect discharge of billions of contaminants of different natures and origins [1-5], which need specific treatment for their removal [6-9]. Potential toxic metals (PTMs) pollution comes from different sources-such as batteries, metal products, and industrial chemical discharge $[10,11]$ - and generates adverse health effects. The presence of PTMs in the environment is increasing in some parts of the world, especially in emerging countries [12-16].

In recent years, cheap and eco-friendly sorbents [17-19] have been used to remove PTMs from wastewater. These sorbents may be considered an alternative to conventional activated carbon-which has a high cost of production and regeneration [20,21]—or ion exchange resins, which are expensive and $\mathrm{pH}$-dependent [22]. Compared to conventional methods, the use of these cheap materials allows for "once-through operations" (i.e., PTM-laden, or exhausted, sorbents can be put into a cement conglomerate as aggregate) $[17,23-26]$, thus overcoming the expensive regeneration procedures and problems related to the large, hazardous sludge production that is typical of traditional sorbents. 
In this paper, a silico-aluminate sorbent, such as expanded perlite, was used to remove lead ions from wastewater. Lead ion was chosen, because it was considered an important pollutant, as it is very toxic to mammals and aquatic life, with its presence in the environment the result of various applications $[27,28]$. The typical concentration of lead ion in industrial wastewater is between $5-15 \mathrm{mg} \cdot \mathrm{L}^{-1}$ for battery production, while for fertilizers, mining, and metallic industries, it is approximately $2 \mathrm{mg} \cdot \mathrm{L}^{-1}$; accordingly, in this study, synthetic lead ion concentration was chosen in a range comparable to industrial practice $\left(2-10 \mathrm{mg} \cdot \mathrm{L}^{-1}\right)[29,30]$. Perlite is a vitreous, volcanic rock that, if heated over $870^{\circ} \mathrm{C}$, expands up to 20 times its original volume, leading to the formation of an excellent thermal insulating and ultra-lightweight material, characterized by interesting mechanical and chemical resistances [31]. For these reasons, and due to its relatively low cost (40-80 USD per $\left.\mathrm{m}^{-3}\right)$, perlite has recently been suggested for many applications, regarding wastewater treatment (i.e., for the synthesis of filtration membranes; as a carrier in biological, fluidized beds; as support for $\mathrm{TiO}_{2}$; and as a sorbent for $\mathrm{Cr}$ (III) ions and dyes) [31-35]. Additionally, the correct adoption of perlite for wastewater treatment may be considered a sustainable solution, as it is in agreement with most of the twelve principles of green chemistry [36].

In this study, packed bed columns were prepared and lead ion separation tests carried out at room temperature and in distilled water, with different sorbent dosages, influent concentrations, and flow-rates being used. The analysis was carried out by evaluating the thermodynamic and kinetic aspects, together with the microstructural characterization, of perlite.

Exhausted perlite residues were reused as cheap and eco-friendly aggregates to produce construction materials-such as cement conglomerates-thus overcoming problems associated with the cost of regeneration. PTM-laden beads can be encapsulated by a matrix, minimizing the leaching of toxic compounds, and are thermal insulating materials with good mechanical resistances $[17,23,24]$. In this respect, conglomerates with increasing perlite volume and with different specific weights were prepared and characterized by thermal mechanical tests.

Consequently, besides proposing a sustainable wastewater treatment, the reuse of exhausted, expanded perlite to increase the insulating properties of cement is in accordance with circular economy principles [37] and with the recent trend towards sustainable water treatments [38-40].

\section{Materials and Methods}

\subsection{The Sorbent}

Perlite was supplied by Maltek Industrie S.r.l. (Terlizzi, Bari, Italy). In the present investigation, grains between 1-2 mm were used, with the following chemical compositions: $\mathrm{SiO}_{2}(74.5 \%), \mathrm{Al}_{2} \mathrm{O}_{3}$ $(12.3 \%), \mathrm{K}_{2} \mathrm{O}(4.2 \%), \mathrm{Na}_{2} \mathrm{O}(4 \%), \mathrm{Fe}_{2} \mathrm{O}_{3}(1 \%)$, and $\mathrm{CaO}(1.4 \%)$. Scannig Electron Microscopy (SEM) and Energy Dispersive X-ray Analysis (EDX) characterization of the particles was carried out by an electron microscope (an Field-emission scanning electron microscopy-Energy Dispersive X-ray Analysis (FESEM-EDX) Carl Zeiss Sigma 300 VP). The samples were applied onto aluminum stubs and covered with carbon film, after sputtering with a Sputter Quorum Q150 thermal evaporator. Perlite porosity determinations were carried out by an Autosorb IQ Chemi TCD instrument (Quantachrome Instruments, Boynton Beach, FL, USA), through adsorption-desorption $\mathrm{N}_{2}$ isotherms, at $77 \mathrm{~K}$.

\subsection{Lead Ion Sorption Tests}

$\mathrm{Pb}\left(\mathrm{NO}_{3}\right)_{2}$ (99.5\%) was purchased from Carlo Erba (Milan, Italy) and the solutions prepared in distilled water $(\mathrm{pH}=6)$. Perlite beads $(1-2 \mathrm{~mm})$ were packed into columns with diameters of $1 \mathrm{~cm}$ and heights of $50 \mathrm{~cm}$. They were then eluted with lead ion solutions. Breakthrough curves were obtained from thermodynamic study. These curves represented the relative lead ion concentration $\left(\mathrm{C} / \mathrm{C}_{0}\right)$ vs. bed volumes $\left(\mathrm{BV}=\mathrm{V} / \mathrm{V}_{0}\right)$. When the liquid-phase solution started to be leached by the column, the breakpoint was reached (i.e., the minimum lead ion retention capacity of the sorbent occurred and the final exhaustion of the bed was obtained, when the concentration of the effluent 
was approximately the same as that of the influent). The first set of experiments was carried out with 2-4 g of perlite at $0.3 \mathrm{~L} \cdot \mathrm{h}^{-1}$ and with $2 \mathrm{mg}$ of $\mathrm{Pb}^{2+} \mathrm{L}^{-1}$. Successively, experiments were carried-out at different influent concentrations $\left(2-10 \mathrm{mg}\right.$ of $\left.\mathrm{Pb}^{2+} \mathrm{L}^{-1}\right)$, at $0.3 \mathrm{~L} \cdot \mathrm{h}^{-1}$, with $4 \mathrm{~g}$ of perlite. Finally, the process was evaluated at variable flow-rates $\left(0.15-0.4 \mathrm{~L} \cdot \mathrm{h}^{-1}\right)$, with $2 \mathrm{mg}$ of $\mathrm{Pb}^{2+} \mathrm{L}^{-1}$ and $4 \mathrm{~g}$ of perlite. Table 1 shows all the experiments performed.

Table 1. Summary of the column tests carried out on the perlite sorbent $(\mathrm{T}=298 \mathrm{~K})$.

\begin{tabular}{cccccccc}
\hline $\begin{array}{c}\text { Test } \\
\text { No. }\end{array}$ & $\begin{array}{c}\text { Flow Rate } \\
\left(\mathbf{L} \cdot \mathbf{h}^{-\mathbf{1}} \mathbf{)}\right.\end{array}$ & $\begin{array}{c}\text { Influent Conc. } \\
\left(\mathbf{m g} \cdot \mathbf{L}^{-\mathbf{1}} \mathbf{)}\right.\end{array}$ & $\begin{array}{c}\text { Bead Size } \\
\mathbf{( \mathbf { m m } )}\end{array}$ & $\begin{array}{c}\text { Bed Volume } \\
\left(\mathbf{c m}^{\mathbf{3}} \mathbf{)}\right.\end{array}$ & $\begin{array}{c}\text { Bed Amount } \\
\mathbf{( g )}\end{array}$ & $\begin{array}{c}\mathbf{Q}_{\mathbf{e x p}} \\
\left(\mathbf{m g} \cdot \mathbf{g}^{\mathbf{- 1}} \mathbf{)}\right.\end{array}$ & BV \\
\hline 1 & 0.3 & 2 & $1-2$ & 16 & 2 & $1.10 \pm 0.05$ & $55 \pm 3$ \\
2 & 0.3 & 2 & $1-2$ & 20 & 2.6 & $1.45 \pm 0.07$ & $80 \pm 4$ \\
3 & 0.3 & 2 & $1-2$ & 24 & 3.2 & $1.7 \pm 0.08$ & $91 \pm 5$ \\
4 & 0.3 & 2 & $1-2$ & 30 & 4 & $2.0 \pm 0.1$ & $100 \pm 5$ \\
5 & 0.3 & 4 & $1-2$ & 30 & 4 & $2.5 \pm 0.12$ & $53 \pm 3$ \\
6 & 0.3 & 7 & $1-2$ & 30 & 4 & $3.1 \pm 0.15$ & $40 \pm 2$ \\
7 & 0.3 & 10 & $1-2$ & 30 & 4 & $3.5 \pm 0.17$ & $27 \pm 1$ \\
8 & 0.15 & 2 & $1-2$ & 30 & 4 & $2.5 \pm 0.12$ & $153 \pm 8$ \\
9 & 0.2 & 2 & $1-2$ & 30 & 4 & $2.2 \pm 0.11$ & $130 \pm 7$ \\
10 & 0.4 & 2 & $1-2$ & 30 & 4 & $1.6 \pm 0.08$ & $73 \pm 4$ \\
\hline
\end{tabular}

Time-dependent breakthrough curves (kinetic study) were also reported. The sorption kinetics are dependent on the mass transfer phenomena [41]. Specifically, film diffusion control is the rate determining step, because functionalities (silico-aluminate groups) are essentially present on the surface of perlite. The half time of the reaction $\left(\mathrm{t}_{0.5}\right)$ was obtained as follows [41]:

$$
\mathrm{t}_{0.5}=1.33 \mathrm{r}_{0} \delta \mathrm{D}^{-1} \mathrm{C}_{0}^{-1} \mathrm{~S}^{-1}
$$

where $t_{0.5}$ is inversely proportional to the bulk specie concentration $\left(C_{0}\right)$ and diffusion coefficient $(D)$, and is directly proportional to the particle radius $\left(\mathrm{r}_{0}\right)$ and film thickness $(\delta)$.

\subsection{Reuse of Perlite Particles in the Construction Field after Lead Exhaustion}

Perlite grains were reused after lead exhaustion and employed as aggregates in cement composites. As binder, 42.5R cement from Buzzi Unicem (Barletta, Italy) [42] was employed, together with silica sand $(0.08-2 \mathrm{~mm})[43,44]$ from Societè Nouvelle du Littoral (Leucate, France). Two sand-containing specimens were prepared as controls: A normalized mortar with a $0.08-2 \mathrm{~mm}$ average grain size range, and a sand reference, with a $0.5-2 \mathrm{~mm}$ average grain size range and an aggregate volume equal to $500 \mathrm{~cm}^{3}$. Perlite beads were used in partial or total substitution of the sand aggregate $(0 \%$, $25 \%, 50 \%, 75 \%$, and $100 \%$ ) and replacement was made based on volume, due to the low specific gravity of the silico-aluminate material. In the case of the perlite samples, a $500 \mathrm{~cm}^{3}$ aggregate volume was used. The water/cement ratio of the specimens was 0.5. Compression tests were carried out (using a MATEST device from Milan, Italy) on samples obtained, following flexural tests, using $40 \times 40 \times 160 \mathrm{~mm}$ prisms [43], and 28 days of curing. Thermal conductivity $(\lambda)$ tests were carried out by an ISOMET 2104 device (Applied Precision Ltd., Bratislava, Slovakia) by application of a heating probe on the surface of cylinders, after 28 days curing. The heating probe had a diameter of $100 \mathrm{~mm}$ and height of $50 \mathrm{~mm}$. Before measurements were taken, the samples were dried at $105^{\circ} \mathrm{C}$, until a constant weight $( \pm 0.5 \%)$ had been reached, and then cooled to room temperature.

\section{Results and Discussion}

\subsection{Perlite Characterization and Perlite as a Lead Ion Sorbent}

Figure 1 shows the morphological structure of a perlite bead, together with its inner porosity. 

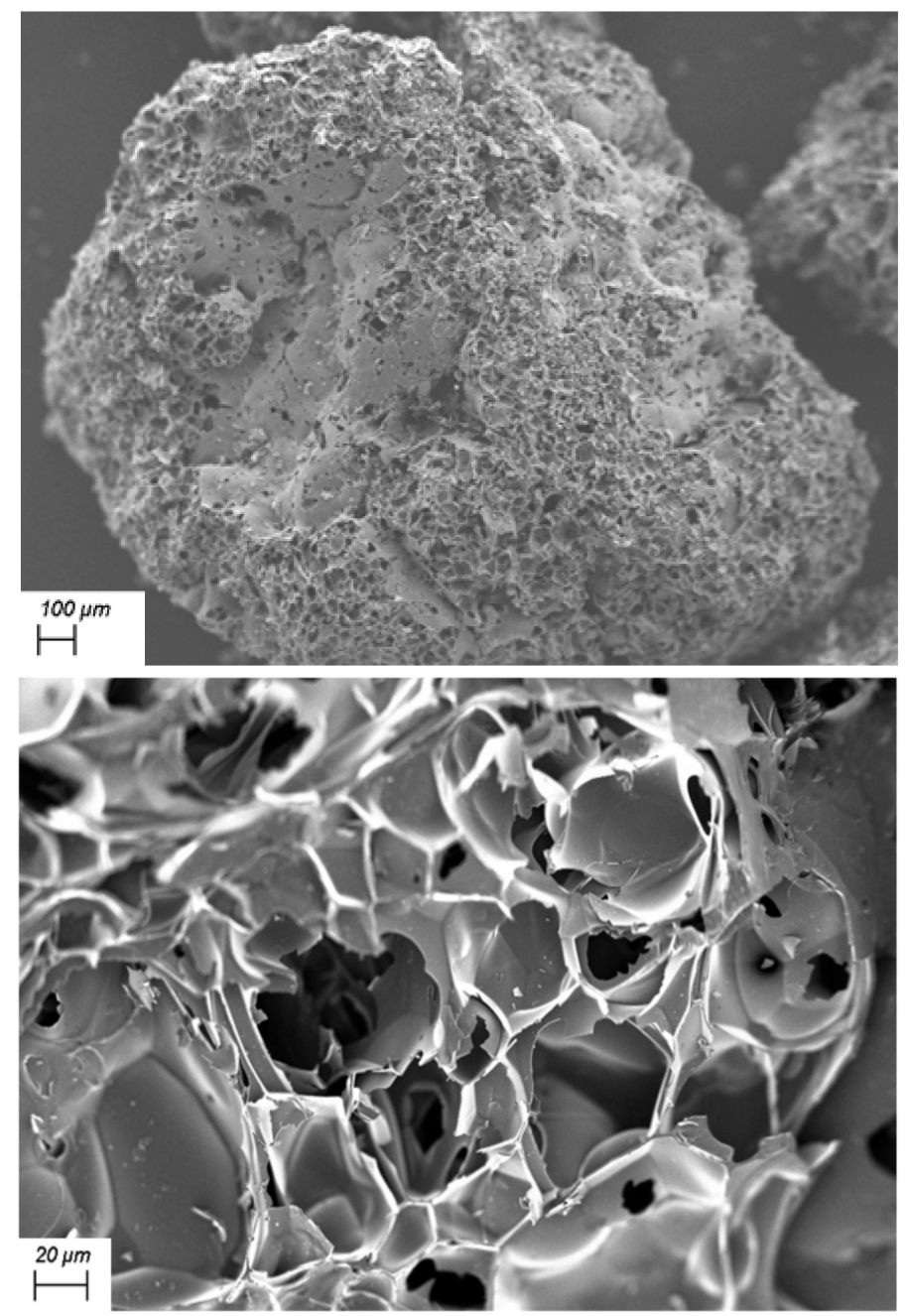

Figure 1. SEM images of the surface of a perlite bead (top) and of the inner perlite structure (bottom).

Perlite is considered a mesoporous material (20-500 $\AA$ pore diameter), with an average pore radius of $16.535 \AA$, a BET total surface area of $1.664 \mathrm{~m}^{2} \cdot \mathrm{g}^{-1}$, a total volume of the pores of $0.008 \mathrm{~cm}^{3} \mathrm{~g}^{-1}$, and a surface area of $1.010 \mathrm{~m}^{2} \cdot \mathrm{g}^{-1}$.

Figure 2 shows the breakthrough curves for experiments carried out at a $0.3 \mathrm{~L} \cdot \mathrm{h}^{-1}$ flow-rate, with $2 \mathrm{mg} \cdot \mathrm{L}^{-1}$ of lead ion concentration and a variable amount $(2-4 \mathrm{~g})$ and bed volume $\left(16-30 \mathrm{~cm}^{3}\right)$ of the sorbent. In these tests, as perlite dosage and volume increased, metal removal efficiency was higher, because a more effective diffusion of lead ions throughout the sorbent was obtained, together with breakpoints reached at increasing bed volumes. Overall retention capacities were experimentally determined at $1.1,1.45,1.7$, and $2.0 \mathrm{mg} / \mathrm{g}_{\text {sorbent }}{ }^{-1}$ and breakpoints were determined at $55,80,91$, and $100 \mathrm{BV}$, respectively, for 2, 2.6, 3.2, and $4 \mathrm{~g}$ of perlite, as shown in Table 1. 

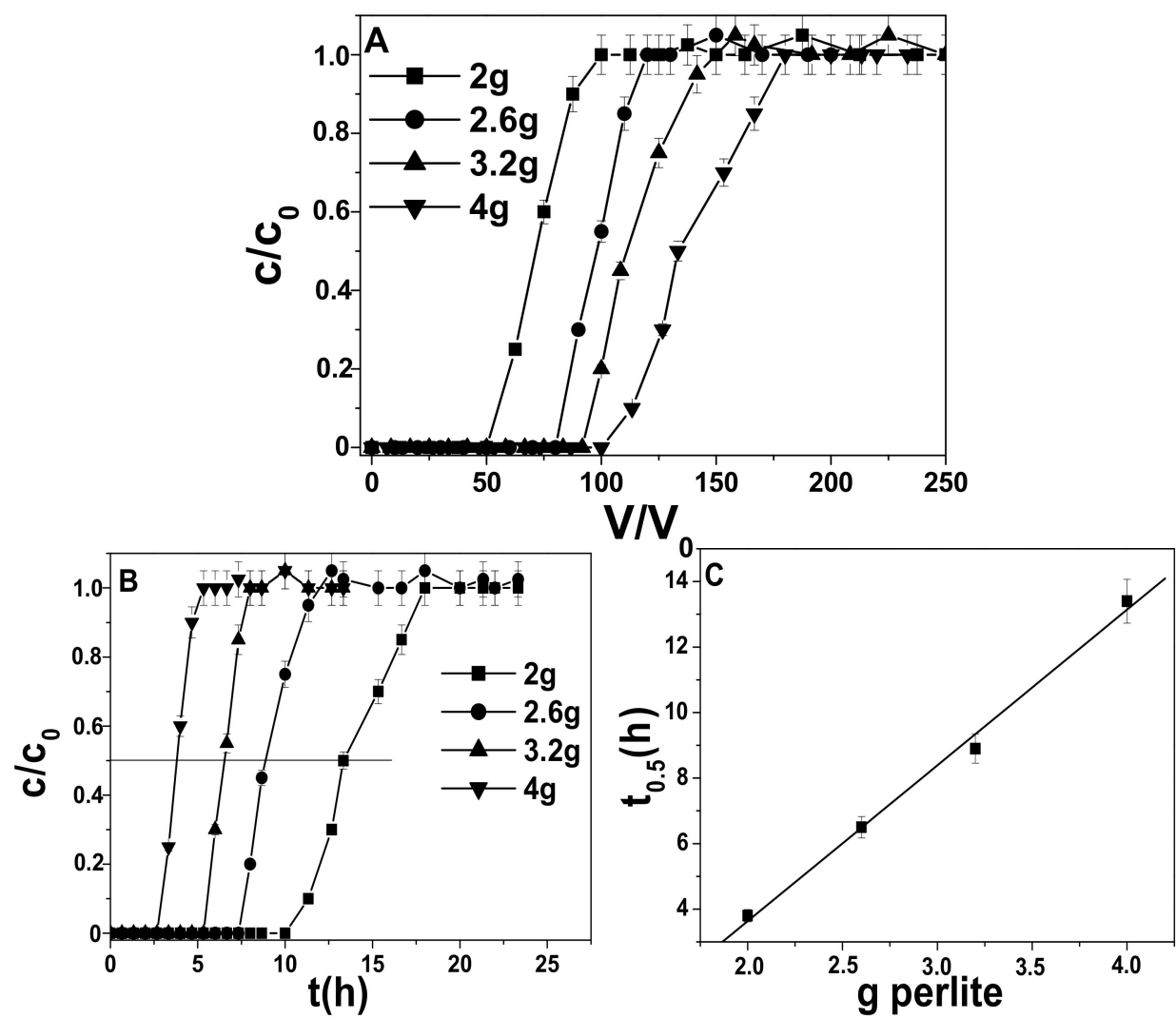

Figure 2. (A) Breakthrough curves for lead ion retention at different perlite dosages $(2,2.6,3.2$, and $4 \mathrm{~g}$; 1-2 $\mathrm{mm}$ bead size range; $0.3 \mathrm{~L} \cdot \mathrm{h}^{-1}$ flow-rate; $2 \mathrm{mg}$ of $\mathrm{Pb}^{+2} \mathrm{~L}^{-1} ; \mathrm{T}=298 \mathrm{~K}$ ). (B) Time-dependent breakthrough curves. (C) Correlation of the half exchange time, $\mathrm{t}_{0.5}$, vs. perlite dosage.

From the reported microscopic observations and Brunauer-Emmett-Teller measurements (BET) measurements, metal retention by the sorbent was ascribed to the specific surface area and to the corresponding large sorbent pores exposed to the liquid-phase, allowing for free migration of the hydrated lead ions ( $4.01 \AA$ hydrated radius) to the functional groups of the silico-aluminate matrix. As previously observed [45], lead ions are mostly absorbed/adsorbed by ion exchange $(65-70 \%)$ - especially with $\mathrm{Na}^{+}$ions, but also with $\mathrm{Ca}^{2+}$ and $\mathrm{K}^{+}$ions-at the negative silicate functional groups present on the perlite surface. This is represented by the following reaction:

$$
\text { nPerlite- }\left(\mathrm{C}^{\mathrm{m}+}\right)+\mathrm{Pb}^{2+} \rightarrow(\text { Perlite })_{\mathrm{n}}-\mathrm{Pb}^{2+}+\mathrm{n}\left(\mathrm{C}^{\mathrm{m}+}\right)
$$

Sorption may also be attributed, on a smaller scale, to Van der Waals forces at non-specific, functional groups.

Figure 2B shows the kinetic study for lead ion retention on perlite, at different sorbent dosages. Time-dependent breakthrough curves showed a direct linear dependence of $\mathrm{t}_{0.5} \mathrm{vs}$. $\mathrm{g}_{\text {sorbent}}$, as demonstrated in Figure 2C.

Figure 3A shows the breakthrough curves for experiments carried out at a $0.3 \mathrm{~L} \cdot \mathrm{h}^{-1}$ flow-rate, with $4 \mathrm{~g}$ of perlite and variable lead ion concentration $\left(2-10 \mathrm{mg}\right.$ of $\left.\mathrm{Pb}^{+2} \mathrm{~L}^{-1}\right)$. 


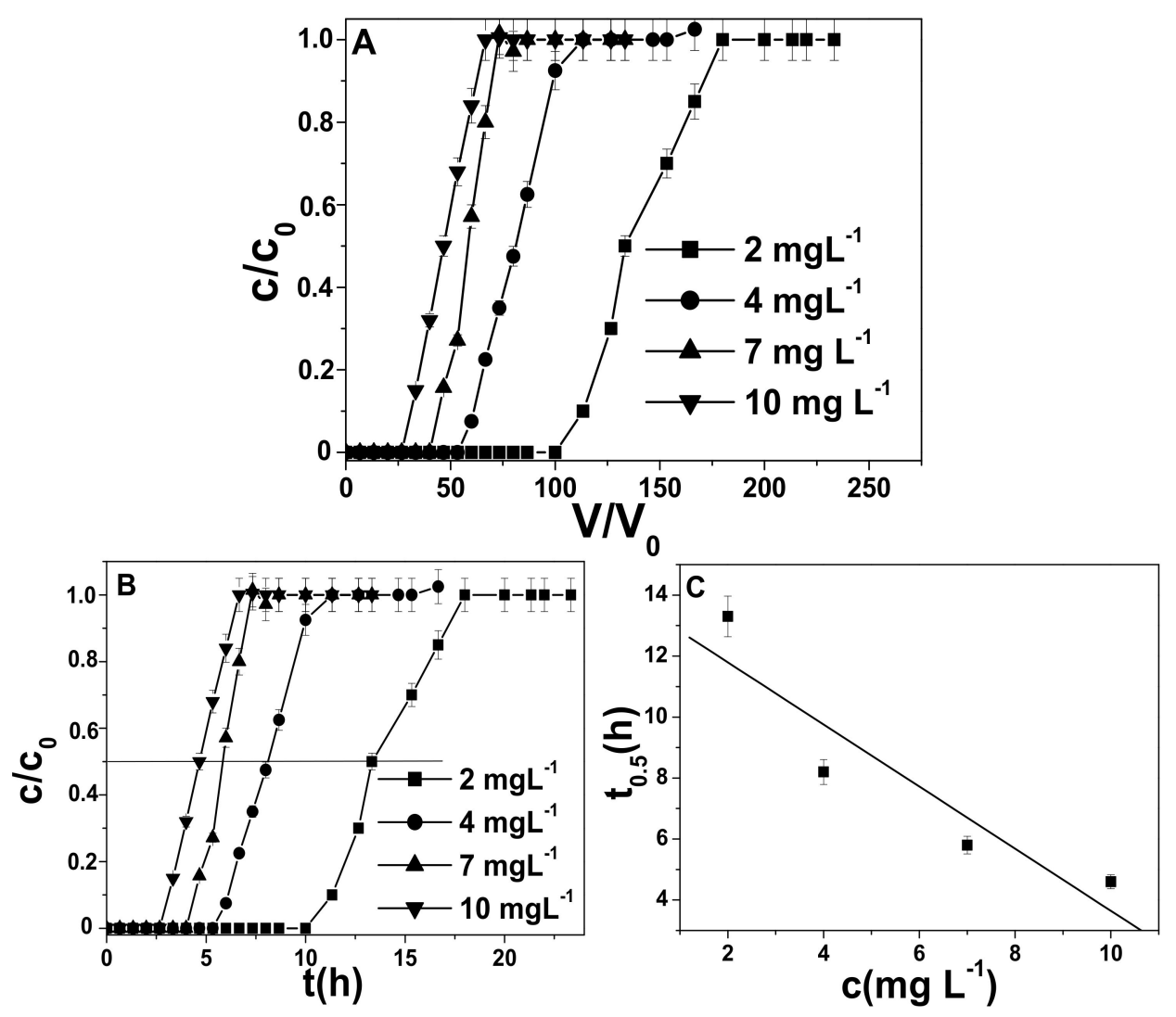

Figure 3. (A) Breakthrough curves for lead ions retention at $2,4,7$, and $10 \mathrm{mg} \mathrm{of} \mathrm{Pb}^{+2} \mathrm{~L}^{-1}\left(0.3 \mathrm{~L} \cdot \mathrm{h}^{-1}\right.$ flow-rate; 4 g perlite; 1-2 mm bead size range; $\mathrm{T}=298 \mathrm{~K}$ ). (B) Time-dependent breakthrough curves. (C) Correlation of the half exchange time, $\mathrm{t}_{0.5}$, vs. influent concentration.

In comparing the curves, it was observed that, as the initial metal concentration $\mathrm{C}_{0}$ increased, an retention capacities also increased, together with anticipation of the breakthrough point (perlite exhaustion). Specifically, for $2,4,7$, and $10 \mathrm{mg} \cdot \mathrm{L}^{-1}$ of lead ion influent concentrations, retention capacities of 2.0, 2.5, 3.1, and $3.5 \mathrm{mg} \mathrm{g}_{\text {sorbent }}{ }^{-1}$, respectively, were obtained, as shown in Table 1 . A concern, regarding the breakpoint, was detected in the case of the most concentrated solution (27 BV, $10 \mathrm{mg}$ of $\mathrm{Pb}^{+2} \mathrm{~L}^{-1}$ ), with respect the $2 \mathrm{mg}$ of $\mathrm{Pb}^{+2} \mathrm{~L}^{-1}$ solution (100 BV). Figure 3B shows the kinetic study of lead ion retention on perlite at different influent concentrations. Quicker saturation of the column was observed at high metal concentrations, thereby decreasing the breakthrough time. Time-dependent breakthrough curves showed a reverse linear dependence of $t_{0.5} \mathrm{vs}$. $\mathrm{C}_{0}$, as shown in Figure 3C, according to the film diffusion control theoretical model (Equation (2)) [41]. Figure 4A shows, the breakthrough curves for experiments carried out with $2 \mathrm{mg}$ of $\mathrm{Pb}^{+2} \mathrm{~L}^{-1}$ influent solution, $4 \mathrm{~g}$ of perlite, and at different flow-rates $\left(0.15,0.2,0.3\right.$, and $\left.0.4 \mathrm{~L} \cdot \mathrm{h}^{-1}\right)$. 


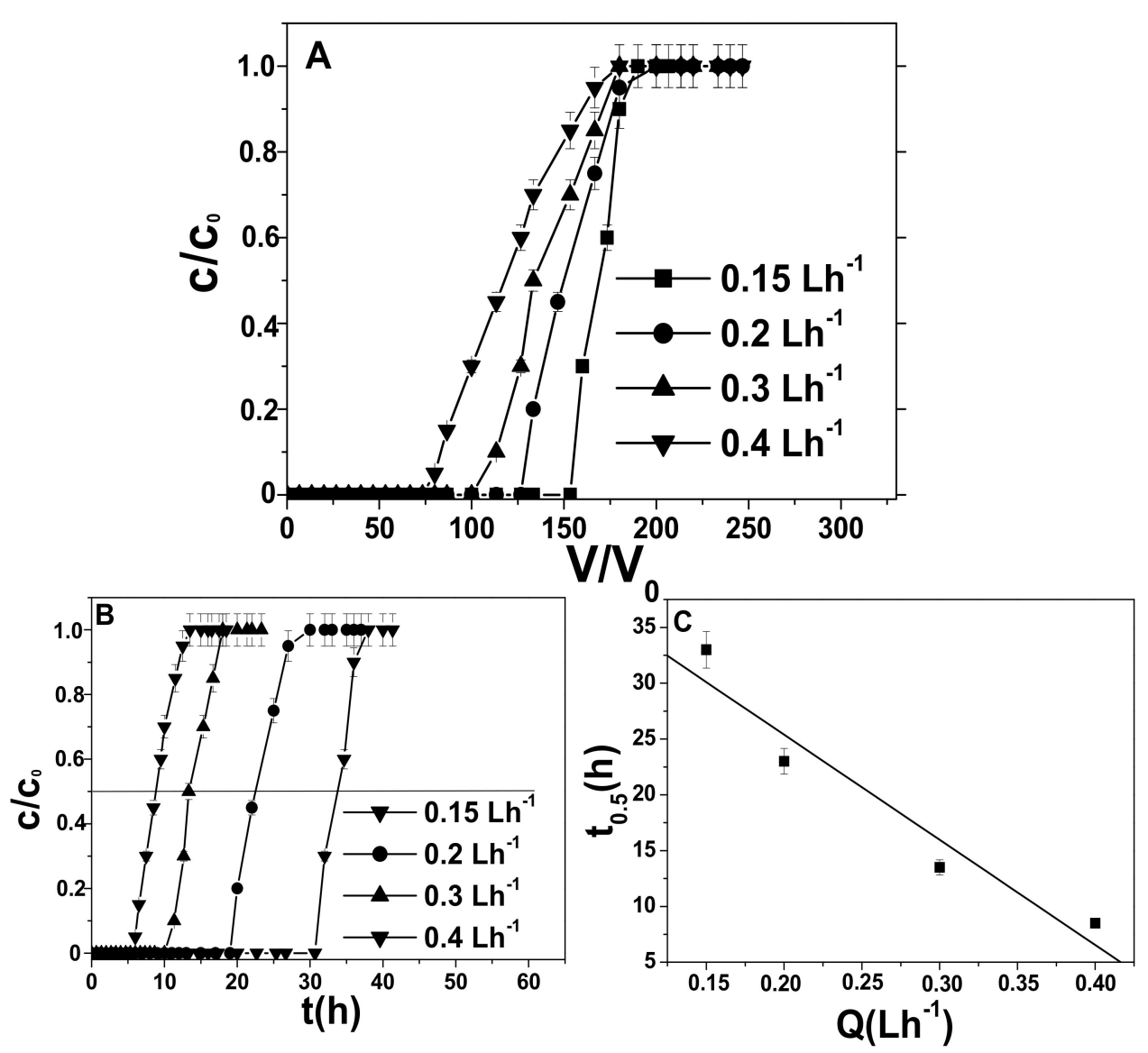

Figure 4. (A) Breakthrough curves for lead ion retention at $0.15,0.2,0.3$, and $0.4 \mathrm{~L} \cdot \mathrm{h}^{-1}$ flow-rates (1-2 mm bead size range; $2 \mathrm{mg}$ of $\mathrm{Pb}^{+2} \mathrm{~L}^{-1} ; 4 \mathrm{~g}$ perlite; $\mathrm{T}=298 \mathrm{~K}$ ). (B) Time-dependent breakthrough curves. (C) Correlation of the half exchange time, $\mathrm{t}_{0.5}$, vs. flow-rate.

Retention capacities were 2.5, 2.2, 2.0, and $1.6 \mathrm{mg} \mathrm{g}_{\text {sorbent }}{ }^{-1}$ for $0.15 \mathrm{~L} \cdot \mathrm{h}^{-1}, 0.2 \mathrm{~L} \cdot \mathrm{h}^{-1}, 0.3 \mathrm{~L} \cdot \mathrm{h}^{-1}$, and $0.4 \mathrm{~L} \cdot \mathrm{h}^{-1}$, respectively, while breakpoints were detected at $153,130,100$, and $73 \mathrm{BV}$, as shown in Table 1. Thus, at low flow-rates, corresponding to long liquid/solid contact times, a more complete saturation of the column was detected. This result explains the increasing retentions and higher values of the breakthrough points. A typical, "self-sharpening" of the column breakthrough curves was observed at lower flow-rates, associated with an increase of metal sorption, as shown in Figure 4A, due to favorable retention equilibria towards the entering ions, occurring when the rates of motion decreased [41]. Figure $4 \mathrm{~B}$ shows the kinetic study for lead ion retention on perlite, at different flow-rates. Slower elution determined a delay of the breakthrough (i.e., higher contact times), while faster elution induced an advance of the breakthrough (i.e., lower contact times). Time-dependent breakthrough curves showed an inverse linear dependence of $\mathrm{t}_{0.5} \mathrm{vs}$. flow-rate, as shown in Figure $4 \mathrm{C}$, according to film diffusion control (Equation (2)) [41]. At lower flow-rates, the film at the liquid/solid interface (Nernst film) could be assumed to be thicker, while at higher flow-rates the film could be assumed to be thinner.

\subsection{Reuse of the Metal Laden Perlite in the Construction Field}

After test no. 7 (4 g of perlite, $0.3 \mathrm{~L} \cdot \mathrm{h}^{-1}$ flow-rate, $10 \mathrm{mg}$ of $\mathrm{Pb}^{+2} \mathrm{~L}^{-1}$ ), exhausted beads were characterized by SEM analysis. No changes were observed on the structure of the sorbent, as shown in Figure 5. 

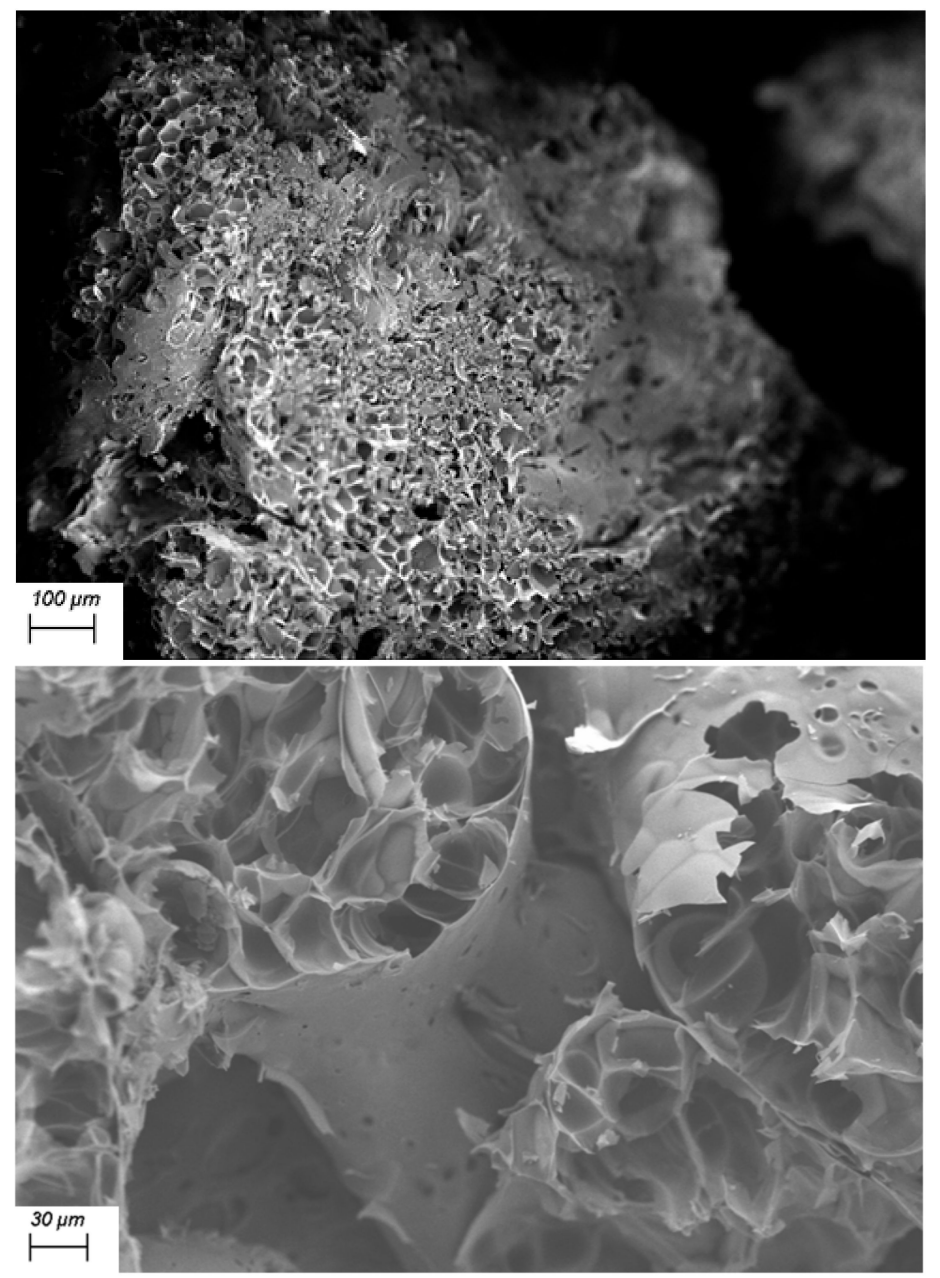

Figure 5. SEM image of a perlite bead, after the sorption process (top) and magnification (bottom).

The silico-aluminate materials were finally reused in the construction field as lightweight aggregates in cement mortars, so as to minimize technical and economic problems related to regeneration processes $[17,23,45,46]$.

As observed in previous studies [47], metals leaching through the composite were few. Accordingly, the specimens were thermally and mechanically characterized, as shown in Table 2 and Figure 6.

Table 2. Thermal and mechanical properties of the controls and perlite-based composites.

\begin{tabular}{|c|c|c|c|}
\hline Sample & $\varrho\left(\mathrm{Kg} \mathrm{m}^{-3}\right)$ & $\lambda\left(\mathrm{W} \mathrm{m}^{-1} \mathrm{~K}^{-1}\right)$ & Rc (Mpa) \\
\hline Normalized mortar & $1960 \pm 100$ & $2.02 \pm 0.10$ & $49 \pm 3$ \\
\hline Sand $(100 \%)$ & $1920 \pm 100$ & $1.59 \pm 0.08$ & $48 \pm 3$ \\
\hline Sand $(75 \%) /$ Perlite $(25 \%)$ & $1750 \pm 88$ & $1.2 \pm 0.06$ & $34.5 \pm 2$ \\
\hline Sand $(50 \%) /$ Perlite $(50 \%)$ & $1600 \pm 80$ & $0.90 \pm 0.05$ & $26 \pm 1$ \\
\hline Sand $(25 \%) /$ Perlite $(75 \%)$ & $1350 \pm 68$ & $0.60 \pm 0.03$ & $21 \pm 1$ \\
\hline Perlite $(100 \%)$ & $1050 \pm 53$ & $0.39 \pm 0.02$ & $16.4 \pm 1$ \\
\hline
\end{tabular}



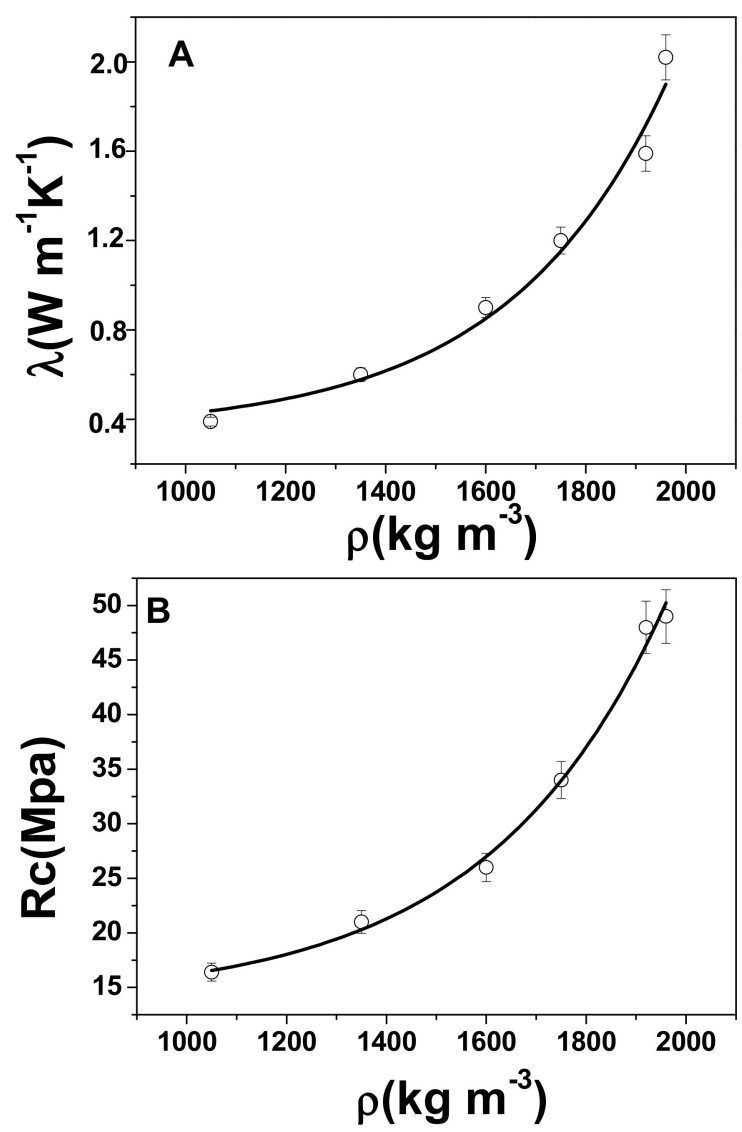

Figure 6. (A) Thermal and (B) mechanical tests of the controls and perlite specimens.

Thermal conductivity, $\lambda$, is the property of a material to transfer heat. It indicates the temperature response of specimens to heat flow impulses [48,49]. Perlite-based mortars showed lower thermal conductivities (from $40 \%$ to $80 \%$ ), compared to the normalized mortar, taken as a control. An increase of perlite content induced an exponential decrease of conductivity, as shown in Figure 6A.

The addition of lightweight aggregates creates voids in the composite matrix, thus sensibly limiting heat transport phenomena. These voids barely contributed to the extended internal porosity of perlite, as shown in Figure 1, as there was a strong adherence at the cement/aggregate interface, as shown in Figure 7. This is opposite to what was observed in composites characterized by cement and organic materials, such as tire rubber, where unfavorable adhesion was observed, due to the different nature of the constituents [50]. In the present example, this perfect adhesion may be ascribed to the similar nature of the compounds present in the ligand paste and aggregates (silicates, aluminates). As perlite volume increased, the thermal insulating properties of the samples improved, due to the decrease in the weight of the composites.

In the case of the resistance to compression tests (after 28 days aging), the perlite-based composites showed a decrease in mechanical performance, with increase of the silico-aluminate aggregate volume, as shown in Figure 6B. This result is in accordance with the thermal measurements, as the weight decrease induced a decrease in mechanical strength, due to the large number of voids introduced into the cement conglomerates. It is also worth to noting that the mechanical performances were extremely interesting, specifically in the case of specimens with $50 \%$ and $75 \%$ perlite, which could be considered a good compromise between thermal insulation and compressive resistance. Applications of these eco-friendly materials may be useful for non-structural composites, such as plaster or panels [24,50,51], thanks to the presence of lightweight, insulating silico-aluminate aggregates. 

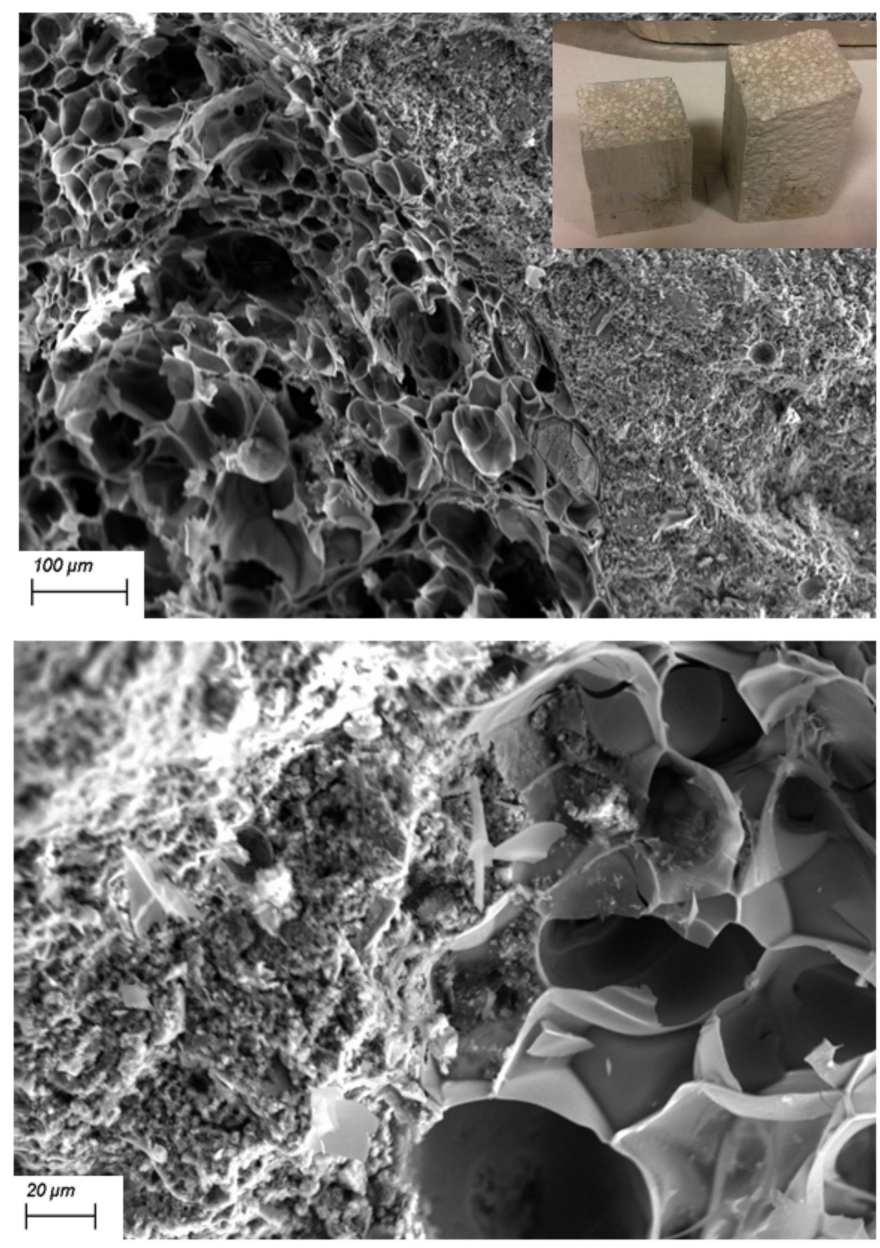

Figure 7. Cement/perlite composites, after mechanical tests (inset), SEM image of the structure of the conglomerate (top) and magnification of the ligand paste/perlite interface (bottom).

\section{Conclusions}

A silico-aluminate material, perlite, was used as an alternative and cheap sorbent of lead ions, present in industrial wastewater. Solutions at different metal concentrations $\left(2-10 \mathrm{mg} \cdot \mathrm{L}^{-1}\right)$ were eluted at different flow-rates $\left(0.15-0.4 \mathrm{~L} \cdot \mathrm{h}^{-1}\right)$ in packed bed columns, filled with different weights $(2-4 \mathrm{~g})$ and volumes $\left(16-30 \mathrm{~cm}^{3}\right)$ of perlite. The main results are summarized as follows:

- $\quad$ From microscopic and BET measurements, metal retention was ascribed to surface area and to the large sorbent pores exposed to the liquid-phase, which allowed for free migration of hydrated lead ions to the functional groups of the silico-aluminate matrix.

- Metal removal efficiencies increased with increasing amounts of perlite, together with breakpoints being reached at increasing bed volumes.

- Increase in retention capacities was observed with an increase of initial metal concentration, together with anticipation of the breakthrough point.

- A more complete saturation of the column was detected at low flow-rates, associated with long liquid/solid contact times, and with corresponding higher values of the breakthrough points.

- $\quad$ The best lead ion retention was obtained at $0.3 \mathrm{~L} \cdot \mathrm{h}^{-1}$, with $4 \mathrm{~g}$ of perlite and $10 \mathrm{mg} \cdot \mathrm{L}^{-1} \mathrm{of} \mathrm{Pb}^{2+}$ (3.5 $\mathrm{mg}$ of $\mathrm{Pb}^{2+} \mathrm{g}_{\text {sorbent }}{ }^{-1}$ ).

- $\quad$ Film diffusion control was the kinetic step of the process.

- After column breakthrough, the sorbent was considered a special waste and incorporated into cement conglomerates as a lightweight, eco-friendly aggregate. 
- With the increase of perlite volume, thermal insulating properties of the samples were improved, together with a decrease in mechanical strength.

- The cement conglomerates could be used in the construction industry in plaster or panels, without adverse environmental effects, as the metals would be incorporated into the matrix, with negligible leaching.

Author Contributions: A.P.: experimental tests and discussion of the results; D.S.: experimental tests and discussion of the results; V.R. and P.C.: characterization of the materials and discussion of the results; M.R.: elaboration data and discussion of the results; N.D.V.: porosity measurements.

Funding: This research received no external funding.

Acknowledgments: The authors thank Adriano Boghetich for the SEM-EDX analysis. Regione Puglia is gratefully acknowledged for her financial support (X-ray Lab Project-Reti di Laboratori Pubblici di Ricerca, cod. n. 45 and 56).

Conflicts of Interest: The authors declare no conflicts of interest.

\section{References}

1. Sharma, N.; Agarwal, A.K.; Eastwood, P.; Gupta, T.; Singh, A.P. Introduction to air pollution and its control. In Air Pollution and Control. Energy, Environment, and Sustainability; Sharma, N., Agarwal, A., Eastwood, P., Gupta, T., Singh, A., Eds.; Springer: Singapore, 2018; pp. 3-7. ISBN 978-981-10-7184-3.

2. Basile, T.; Petrella, A.; Petrella, M.; Boghetich, G.; Petruzzelli, V.; Colasuonno, S.; Petruzzelli, D. Review of endocrine-disrupting-compound removal technologies in water and wastewater treatment plants: An EU perspective. Ind. Eng. Chem. Res. 2011, 50, 8389-8401. [CrossRef]

3. Wu, J.; Zhu, G.; Yu, R. Fates and impacts of nanomaterial contaminants in biological wastewater treatment system: A review. Water Air Soil Pollut. 2018, 229, 9. [CrossRef]

4. Cachada, A.; Rocha-Santos, T.; Duarte, A.C. Soil and pollution: An introduction to the main issues. In Soil Pollution, 1st ed.; Duarte, A., Cachada, A., Rocha-Santos, T., Eds.; Elsevier: Amsterdam, The Netherlands, 2018; pp. 1-28.

5. Spasiano, D.; Luongo, V.; Petrella, A.; Alfè, M.; Pirozzi, F.; Fratino, U.; Piccinni, A.F. Preliminary study on the adoption of dark fermentation as pretreatment for a sustainable hydrothermal denaturation of cement-asbestos composites. J. Clean. Prod. 2017, 166, 172-180. [CrossRef]

6. Dmitrienko, M.A.; Strizhak, P.A. Coal-water slurries containing petrochemicals to solve problems of air pollution by coal thermal power stations and boiler plants: An introductory review. Sci. Total Environ. 2018, 613, 1117-1129. [CrossRef] [PubMed]

7. O'Brien, P.L.; DeSutter, T.M.; Casey, F.X.; Khan, E.; Wick, A.F. Thermal remediation alters soil properties-A review. J. Environ. Manag. 2018, 206, 826-835. [CrossRef] [PubMed]

8. Petrella, A.; Boghetich, G.; Petrella, M.; Mastrorilli, P.; Petruzzelli, V.; Petruzzelli, D. Photocatalytic degradation of azo dyes. Pilot plant investigation. Ind. Eng. Chem. Res. 2014, 53, 2566-2571. [CrossRef]

9. Petrella, A.; Mascolo, G.; Murgolo, S.; Petruzzelli, V.; Ranieri, E.; Spasiano, D.; Petruzzelli, D. Photocatalytic oxidation of organic micro-pollutants: Pilot plant investigation and mechanistic aspects of the degradation reaction. Chem. Eng. Commun. 2016, 203, 1298-1307. [CrossRef]

10. Zhang, K.; Chai, F.; Zheng, Z.; Yang, Q.; Zhong, X.; Fomba, K.W.; Zhou, G. Size distribution and source of heavy metals in particulate matter on the lead and zinc smelting affected area. J. Environ. Sci. 2018, 71, 188-196. [CrossRef] [PubMed]

11. Fu, F.; Wang, Q. Removal of heavy metal ions from wastewaters: A review. J. Environ. Manag. 2011, 92, 407-418. [CrossRef] [PubMed]

12. Ranieri, E.; Fratino, U.; Petrella, A.; Torretta, V.; Rada, E.C. Ailanthus Altissima and Phragmites Australis for chromium removal from a contaminated soil. Environ. Sci. Pollut. R. 2016, 23, 15983-15989. [CrossRef] [PubMed]

13. Fabbricino, M.; Ferraro, A.; Luongo, V.; Pontoni, L.; Race, M. Soil washing optimization, recycling of the solution, and ecotoxicity assessment for the remediation of Pb-contaminated sites using EDDS. Sustainability 2018, 10, 636. [CrossRef] 
14. Petruzzelli, D.; Petruzzelli, V.; Basile, T.; Petruzzelli, M.; Petrella, A.; Maggiore, M. Chemical and geochemical characterisation of a disused red brick factory area of central Italy. Chem. Ecol. 2011, 27, 143-152. [CrossRef]

15. Bairq, Z.A.S.; Li, R.; Li, Y.; Gao, H.; Sema, T.; Teng, W.; Kumar, S.; Liang, Z. New advancement perspectives of chloride additives on enhanced heavy metals removal and phosphorus fixation during thermal processing of sewage sludge. J. Clean. Prod. 2018, 188, 185-194. [CrossRef]

16. Shahat, A.; Hassan, H.M.; Azzazy, H.M.; El-Sharkawy, E.A.; Abdou, H.M.; Awual, M.R. Novel hierarchical composite adsorbent for selective lead (II) ions capturing from wastewater samples. Chem. Eng. J. 2018, 332, 377-386. [CrossRef]

17. Petrella, A.; Petrella, M.; Boghetich, G.; Basile, T.; Petruzzelli, V.; Petruzzelli, D. Heavy metals retention on recycled waste glass from solid wastes sorting operations: A comparative study among different metal species. Ind. Eng. Chem. Res. 2012, 51, 119-125. [CrossRef]

18. Wang, B.; Zhou, Y.; Li, L.; Xu, H.; Sun, Y.; Wang, Y. Novel synthesis of cyano-functionalized mesoporous silica nanospheres (MSN) from coal fly ash for removal of toxic metals from wastewater. J. Hazard. Mater. 2018, 345, 76-86. [CrossRef] [PubMed]

19. Nguyen, T.C.; Loganathan, P.; Nguyen, T.V.; Kandasamy, J.; Naidu, R.; Vigneswaran, S. Adsorptive removal of five heavy metals from water using blast furnace slag and fly ash. Environ. Sci. Pollut. Res. 2018, 25, 20430-20438. [CrossRef] [PubMed]

20. Crini, G. Recent developments in polysaccharide-based materials used as adsorbents in wastewater treatment. Prog. Polym. Sci. 2005, 30, 38-70. [CrossRef]

21. Kucinska, A.; Cyganiuk, A.; Lukaszewicz, J.P. A microporous and high surface area active carbon obtained by the heat-treatment of chitosan. Carbon 2012, 50, 3098-3101. [CrossRef]

22. Sun, X.; Li, Q.; Yang, L.; Liu, H. Removal of chromium(VI) from wastewater using weakly and strongly basic magnetic adsorbents: Adsorption/desorption property and mechanism comparative studies. RSC Adv. 2016, 6, 18471-18482. [CrossRef]

23. Petrella, A.; Petruzzelli, V.; Ranieri, E.; Catalucci, V.; Petruzzelli, D. Sorption of Pb(II), Cd(II) and Ni(II) from single- and multimetal solutions by recycled waste porous glass. Chem. Eng. Commun. 2016, 203, 940-947. [CrossRef]

24. Petrella, A.; Spasiano, D.; Acquafredda, P.; De Vietro, N.; Ranieri, E.; Cosma, P.; Rizzi, V.; Petruzzelli, V.; Petruzzelli, D. Heavy metals retention (Pb (II), Cd (II), Ni (II)) from single and multimetal solutions by natural biosorbents from the olive oil milling operations. Process Saf. Environ. 2018, 114, 79-90. [CrossRef]

25. Coppola, L.; Bellezze, T.; Belli, A.; Bignozzi, M.C.; Bolzoni, F.; Brenna, A.; Cabrini, M.; Candamano, S.; Cappai, M.; Caputo, D.; et al. Binders alternative to Portland cement and waste management for sustainable construction-Part 2. J. Appl. Biomater. Funct. Mater. 2018, 16, 207-221. [CrossRef] [PubMed]

26. Coppola, L.; Bellezze, T.; Belli, A.; Bignozzi, M.C.; Bolzoni, F.; Brenna, A.; Cabrini, M.; Candamano, S.; Cappai, M.; Caputo, D.; et al. Binders alternative to Portland cement and waste management for sustainable construction-part 1. J. Appl. Biomater. Funct. Mater. 2018, 16, 186-202. [PubMed]

27. Turan, M.; Mart, U.; Yüksel, B.; Celik, M.S. Lead removal in fixed-bed columns by zeolite and sepiolite. Chemosphere 2005, 60, 1487-1492. [CrossRef] [PubMed]

28. Senthilkumar, R.; Vijayaraghavan, K.; Thilakavathi, M.; Iyer, P.V.R.; Velan, M. Application of seaweeds for the removal of lead from aqueous solution. Biochem. Eng. J. 2007, 33, 211-216. [CrossRef]

29. Abdel-Halim, S.H.; Shehata, A.M.A.; El-Shahat, M.F. Removal of lead ions from industrial waste water by different types of natural materials. Water Res. 2003, 37, 1678-1683. [CrossRef]

30. Bahadir, T.; Bakan, G.; Altas, L.; Buyukgungor, H. The investigation of lead removal by biosorption: An application at storage battery industry wastewaters. Enzym. Microb. Technol. 2007, 41, 98-102. [CrossRef]

31. Chakir, A.; Bessiere, J.; Kacemi, K.E.; Marouf, B. A comparative study of the removal of trivalent chromium from aqueous solutions by bentonite and expanded perlite. J. Hazard. Mater. 2002, 95, 29-46. [CrossRef]

32. Doğan, M.; Alkan, M. Adsorption kinetics of methyl violet onto perlite. Chemosphere 2003, 50, 517-528. [CrossRef]

33. Sowmeyan, R.; Swaminathan, G. Evaluation of inverse anaerobic fluidized bed reactor for treating high strength organic wastewater. Bioresour. Technol. 2008, 99, 3877-3880. [CrossRef] [PubMed]

34. Shavisi, Y.; Sharifnia, S.; Hosseini, S.N.; Khadivi, M.A. Application of $\mathrm{TiO}_{2}$ / perlite photocatalysis for degradation of ammonia in wastewater. J. Ind. Eng. Chem. 2014, 20, 278-283. [CrossRef] 
35. Saja, S.; Bouazizi, A.; Achiou, B.; Ouammou, M.; Albizane, A.; Bennazha, J.; Younssi, S.A. Elaboration and characterization of low-cost ceramic membrane made from natural Moroccan perlite for treatment of industrial wastewater. J. Environ. Chem. Eng. 2018, 6, 451-458. [CrossRef]

36. Anastas, P.; Eghbali, N. Green chemistry: Principles and practice. Chem. Soc. Rev. 2010, 39, 301-312. [CrossRef] [PubMed]

37. Tukker, A. Product services for a resource-efficient and circular economy-A review. J. Clean. Prod. 2015, 97, 76-91. [CrossRef]

38. Razali, M.; Kim, J.F.; Attfield, M.; Budd, P.M.; Drioli, E.; Lee, Y.M.; Szekely, G. Sustainable wastewater treatment and recycling in membrane manufacturing. Green Chem. 2015, 17, 5196-5205. [CrossRef]

39. Li, Y.; Liu, J.; Yuan, Q.; Tang, H.; Yu, F.; Lv, X. A green adsorbent derived from banana peel for highly effective removal of heavy metal ions from water. RSC Adv. 2016, 2, 45041-45048. [CrossRef]

40. Ranieri, E.; Gorgoglione, A.; Petrella, A.; Petruzzelli, V.; Gikas, P. Benzene removal in horizontal subsurface flow constructed wetlands treatment. Int. J. Appl. Eng. Res. 2015, 10, 14603-14614.

41. Petrella, A.; Petruzzelli, V.; Basile, T.; Petrella, M.; Boghetich, G.; Petruzzelli, D. Recycled porous glass from municipal/industrial solid wastes sorting operations as a lead ion sorbent from wastewaters. React. Funct. Polym. 2010, 70, 203-209. [CrossRef]

42. Italian Organization for Standardization (UNI). Cement Composition, Specifications and Conformity Criteria for Common Cements. EN 197-1. Available online: http://store.uni.com/magento-1.4.0.1/index.php/en197-1-2011.html (accessed on 14 September 2011).

43. Italian Organization for Standardization (UNI). Methods of Testing Cement-Part 1: Determination of Strength. EN 196-1. Available online: http:/ / store.uni.com/magento-1.4.0.1/index.php/en-196-1-2016.html (accessed on 27 April 2016).

44. International Organization for Standardization (ISO). Cement, Test Methods, Determination of Strength. ISO 679. Available online: http:/ / store.uni.com/magento-1.4.0.1/index.php/iso-679-2009.html (accessed on 24 April 2009).

45. Petrella, A.; Cosma, P.; Rizzi, V.; De Vietro, N. Porous alumosilicate aggregate as lead ion sorbent in wastewater treatments. Separations 2017, 4, 25. [CrossRef]

46. Paul, S.C.; Šavija, B.; Babafemi, A.J. A comprehensive review on mechanical and durability properties of cement based materials containing waste recycled glass. J. Clean. Prod. 2018, 198, 891-906. [CrossRef]

47. Italian Organization for Standardization (UNI). Characterization of Waste-Compliance Test for Leaching of Granular Waste Materials and Sludges. EN 12457-2. Available online: http:/ / store.uni.com/magento-1.4.0. 1/index.php/en-12457-2-2002.html (accessed on 18 September 2002).

48. Mills, A.F. Basic Heat and Mass Transfer, 2nd ed.; Prentice Hall: Upper Saddler River, NJ, USA, 1999; Volume 2, pp. 745-833, ISBN 978-0130962478.

49. Ahmadi, P.F.; Ardeshir, A.; Ramezanianpour, A.M.; Bayat, H. Characteristics of heat insulating clay bricks made from zeolite, waste steel slag and expanded perlite. Ceram. Int. 2018, 44, 7588-7598. [CrossRef]

50. Di Mundo, R.; Petrella, A.; Notarnicola, M. Surface and bulk hydrophobic cement composites by tyre rubber addition. Constr. Build. Mater. 2018, 172, 176-184. [CrossRef]

51. Liuzzi, S.; Rubino, C.; Stefanizzi, P.; Petrella, A.; Boghetich, A.; Casavola, C.; Pappalettera, G. Hygrothermal properties of clayey plasters with olive fibers. Constr. Build. Mater. 2018, 158, 24-32. [CrossRef]

(C) 2018 by the authors. Licensee MDPI, Basel, Switzerland. This article is an open access article distributed under the terms and conditions of the Creative Commons Attribution (CC BY) license (http://creativecommons.org/licenses/by/4.0/). 